\title{
49-N. G. Çernişevski’nin Nasıl Yapmalı? adlı romanında "yeni insan” tipleri
}

\section{Güneş SÜTCய̈²} APA: Güneş, S. (2020). N. G. Çernişevski'nin Nasıl Yapmalı? adlı romanında “yeni insan” tipleri.
RumeliDE Dil ve Edebiyat Araştırmaları Dergisi, (21), 801-810. DOI: 10.2900o/rumelide.835769.

\section{$\ddot{\mathbf{O} z}$}

XIX. yüzyıl, Rus edebiyat tarihinde dünya yazınına kazandırdığı yazarlar ve eserler nedeniyle "altın çă̆” olarak adlandırılan bir dönemdir. Bu dönemin önemli yazarlarından biri, devrimci demokrat kimliğiyle bilinen Nikolay Gavriloviç Çernişevski'dir. Yazarın 1863 yılında yayımlanan Nasıl yapmalı? (Что делать) adlı romanı, 1860’lı yılların genç neslinin karakteristik özelliklerini vermesi açısından önemli bir yere sahiptir. Romanda yeni nesil Rus insanının düşünce dünyasının aktarılmasına aracılık eden kahramanlar, "yeni insan” tipinin canlı örnekleri olarak karşımıza çlkmaktadır. Bu anlamda geleceğin ideal toplumunu temsil eden ve yeni ahlaki değerleri savunan “yeni insan” yüzyıl Rus edebiyatında beliren "yeni insan" tipinin tanımlanması, ortaya çıkış nedenlerinin ve karakteristik özelliklerinin ayrıntılarıyla ortaya konulması amaçlanmaktadır. Çernişevski romanında kahramanların oynadıkları rolü ve kendi dünya görüşüne göre içinde bulunduğu dönemin en belirgin özelliklerini bünyesinde taşıyan "yeni insan" tiplerini ayrıntılı bir biçimde betimlemiştir. Yazar kendi deyimiyle yeni neslin sıradan erdemli insanlarını tanıtmak ister. Bu düşünceyle ortaya çıkan ve büyük tartışmalara neden olan Nasıl Yapmalı? yeni nesil Rus insanının değer yargılarını en gerçekçi biçimde gözler önüne serme özelliği taşımaktadır. Sonuç kısmında elde edilen bulgular ışığında Çernişevski’nin "yeni insan” tiplerinin güçlü bir iradeye sahip, rasyonalist, eylem insanı, mutluluk odaklı, pragmatizmi benimsemiş ve topluma rol model oldukları anlaşılmıştır.

Anahtar kelimeler: Rus edebiyatı, yeni insan, tip, Çernişevski, Nasıl Yapmalı

\section{Types of "new people” in Chernyshevsky's "What Is To Be Done?"}

\begin{abstract}
XIX. century is a period in the history of Russian literature that is regarded as a "golden age" due to the writers and works that it contributed to world literature. One of the important writers of this period is Nikolay Gavrilovic Chernishevsky, known for his revolutionary democrat identity. The author's What Is To Be Done?, published in 1863. His novel (Что делать) gives the characteristic features of the young generation of the 1860 s. In the novel, the protagonists who mediate the world of thought of the new generation of Russian people are living examples of the "new human" type. In this sense, the representatives of the "new man" who represent the ideal society of the future and defend new moral values are Lopuhov, Kirsanov, Vera Pavlovna and Rahmetov. In this work, it is aimed to define the "new person" type that appeared in XIX. century Russian literature, to reveal the reasons for its emergence and its characteristic features in detail. In his novel, Chernishevsky
\end{abstract}

Bu makale, II. Uluslararası Türk-Rus Dünyası Akademik Araştırmalar Kongresinde (UTRAK-2019) sunulan bildirinin genişletilip yeniden düzenlenmiş halidir.

Dr. Öğr. Gör., Anadolu Üniversitesi, Edebiyat Fakültesi, Rus Dili ve Edebiyatı (Eskişehir, Türkiye), gunessutcu@anadolu.edu.tr, ORCID ID: oooo-0001-9496-4051 [Araştırma makalesi, Makale kayıt tarihi: 21.09.2020kabul tarihi: 20.12.2020; DOI: 10.29000/rumelide.835769]

Adres 
has described in detail the most prominent features of his worldview, the types of "new people", through his heroes. The author, in his own words, wants to introduce ordinary but virtuous people of the new generation. The "What Is To Be Done?" named novel has the feature of revealing the value judgements of the new generation Russian people in the most realistic way. According to the evaluation in the conclusion part, it has been understood that Chernyshevsky's "new people" types have a strong will, rationalist, activist, happiness-oriented, pragmatic and role models for society.

Keywords: Russian literature, new person, type, Chernyshevsky, What Is To Be Done

\title{
1. Giriş
}

\author{
“Özgürlüğün olmadı̆̆ı yerde \\ mutluluk da yoktur.” \\ N. G. Çernişevski
}

Ünlü Rus yazar, edebiyat eleştirmeni ve düşünür kimliğiyle Nikolay Gavriloviç Çernişevski (18281889) XIX. yüzyılın en çarpıcı devrimci demokrat temsilcilerinden biridir. Çernişevski, 1860'ların radikal demokratlarının ideolojisini savunur ve "Aydınlanma" akımının mihenk taşını oluşturur. İlk olarak St. Sergiyus Kilisesi’nin papazlarından birinin oğlu olan Çernişevski, papaz olarak yetiştirilmeyi reddederek St. Petersburg'daki tarih ve filoloji fakültesine girer. Burada halkın erişimine izin verilmeyen ve yasaklanmış kitapları okuma imkânı bulur (Walicki, 2009: 292). Çernişevski, toprak köleliğinin ${ }^{3}$ Tanrısal bir kökene dayandırıldığının anlatıldığı, felsefenin tamamen yasaklandığı ve baskıcı bir tutumu benimseyen Petersburg Üniversitesinde eğitim alırken büyük bir hayal kırıklığı yaşar. Bu nedenle kendi imkanlarıyla bilhassa felsefe alanında okumalar yapan Çernişevski, Belinski ve Hertsen'in eserleriyle yakından ilgilenir. Bu farkındalıklar ışı̆̆ında Çernişevski, dönemin Rus toplumundaki yozlaşmışlıkları ve adaletsizlikleri daha iyi anlar. Bu nedenle devrimin kaçınılmaz bir tercih olduğu inancındadır. Bu düşüncelerini paylaştığı yazılarla Çernişevski, Çar II. Aleksandr'ın ve yönetimin dikkatini çeker. 1862 yılında hiçbir geçerli sebep olmadan tutuklanır ve sürgüne gönderilir. 27 yll süren sürgün sonunda 1889 yllında Saratov'a döner ve sağlık durumunun kötüleşmesiyle hayatını kaybeder (Süer, 1994: 87-88).

\section{N. G. Çernişevski’nin “yeni insan” tipleri}

Yazar, içinde yaşadığı dönemde kendi neslinin insanlarına nasıl yaşanması gerektiğini açılamaya çalışıp onlar için "bir hayat ansiklopedisi” yaratma düşüncesiyle Nasıl Yapmalı? adlı romanını kaleme alır (Çernişevski, 1937: 74). İçinde bulunduğu toplumun mevcut düzenle yönetilmesinin yanlış olduğunu savunur ve bunun yerine düşlerindeki ideal toplum düzenini ifade etmek amacındadır. O dönem için ütopya niteliği taşıyan yazarın toplum düzeni anlayışı için yapabileceği tek eylem, yazmaktır. 112 gün (14 Aralık 1862 - 4 Nisan 1863) gibi kısa bir süre zarfında romanını tamamlar. Nasıl Yapmalı? Souremennik4 dergisinde yayımlanır.

3 Toprak köleliği reformu 1861 tarihinde gerçekleştirilir. Ancak 1861 toprak reformu yeterince ileri bir reform değildir: Köylülerin toprağa karşı açlı derecesindeki gereksinimlerini doyuramadı ve daha önce köylüler tarafından işletilen toprakların birkaç dönümünü, onların ellerinden aldı; hükümetin eski serf sahiplerine verdiği tazminatı karşılamak için, köylülere ağır kurtulmalık ödentileri yüklendi. Kısacası, tarım sorunu nihai bir çözüme ulaştırılamamıştı ve çarcı mutlakçılığın yapısı değişmeden kalmıştı. Tüm bunlara karşın, Rusya'nın bu tarihlerde hızlı bir kapitalist gelişme içine girdiği ve ülkenin düşünce ikliminde derin değişikliklerin görüldü̆ğü de bir gerçektir. Bkz: Walicki, A. (2009). Rus Düsünce Tarihi Aydınlanma'dan Marksizme. (Çev. Alaeddin Şenel.) İletişim Yayınları. s. 288

${ }^{4}$ Genel olarak Souremennik, dönemin felsefi arayışlarından ve tartışmalarından uzak durmaya çalışmıştır. Başlıca amacı olan edebiyat ve eleştirinin yanı sıra, edebiyat tarihine de yer verilmiştir. 1846 yılında ise Sovremennik'in başına

Adres
Address

Istanbul Medeniyet University, Faculty of Education Sciences,

Turkish and Social Scinces Education, Turkish Language Teaching

Education, Cevizli Campus, Kartal-İstanbul /TURKEY

e-mail: editor@rumelide.com 
Romanın ana konusu, Rusya’ya yeni bir kan akışını sağlayacak olan "yeni insan” tiplerini tanıtmak ve değişen toplum düzeni sonrasında hayatın nasıl olacağını anlatmaktır. Çernişevski’nin bu eseri ilk bakışta tipik bir aşk romanı gibi görünse de roman yayımlandığı an itibariyle, insanları devlet düzenine karşı kışkırtması ve anarşist fikirler içermesi nedeniyle eleştirilir. Buna karşılık yapılan eleştiriler, insanların romana karşı daha fazla merak duymasını sağlar. Rus devrimci P. Kropotkin’in düşüncesine göre Nasıl Yapmalı? Rus gençliği için adeta bir bayrak niteliği taşır (Süer, 1994: 91). Rus edebiyat eleştirmeni Pyotr Vail (1991: 128) "Yüzyılın Romanı" (Роман века) adlı makalesinde Nasıl Yapmah? romanının "Rus edebiyatının bilinçli olarak yazılmış ilk avangard romanı" olduğunu belirtir. M.T. Pinayev, D.İ. Pisarev, A.P. Skaftımov, N.N. Strahov gibi edebiyat eleştirmenleri ise Çernişevski'nin "yeni insanlar"ını tanımlamaya çalışılar. Bununla birlikte Nasıl Yapmalı? adlı romanın İ.S. Turgenyev'in Babalar ve Oğullar (1861) adlı romanına bir yanıt niteliği taşıdığını belirtmek gerekmektedir. Çernişevski, Turgenyev'in nihilist tiplerinin karşısına antitez olarak kendi yarattığı “yeni insanlar” konumlandırır. Turgenyev'in romanının sonunda Bazarov'un trajedisi, içinde bulunduğu topluma kendini ait hissetmemesi ve buna bağlı olarak çektiği yalnızlıkla ilişkilendirilir. Çernişevski'de ise bu durumun aksine "mutlu insanlar" söz konusudur. Bu düşünceyi destekleyen Strahov'a göre yeni insanlar "mutlu", Pisarev'e göre ise "iуi” insanlardır (Балахоновая, 2018: 27-28). Pinayev'e göre (1980) ise Çernişevski’nin romanı Rus edebiyatındaki gerçekçiliğin sınırlarını genişletmekle kalmaz, aynı zamanda yarattığı "yeni insan" tipleri ile devrimci, demokrat ve sosyalist düşünceleri edebiyata dahil eder. Buna benzer tartışmalar karşısında Çernişevski (1937: 117) "yeni neslin sıradan erdemli insanlarını betimlemek istemiştim" diyerek kendini ifade eder. Çünkü yazar, bilhassa bu dönemde “yeni insanlar”ın geleceğin aydınlık Rusya'sı için öneminin farkındadır.

Düşlenen yeni düzenin kuruluşunu sağlayacak ve topluma nefer olacak kişiler, Çernişevski’nin “yeni insan"larıdır. Bunlar Vera Pavlovna, Lopuhov, Kirsanov ve Rahmetov'dur. Adı geçen kahramanların ortak özelliği, eylem insanı olmalarıdır. Alman yazar Johann Wolfgang Von Goethe'nin "Bilmek yetmez, uygulamak gerekir. İstemek yetmez, yapmak gerekir" (Franckh, 2020: 105) sözlerinde vurguladığı gibi eylemleriyle varlıklarını ifşa ederler. Çernişevski için eylem insanı olan "yeni insan”lar, içinde taşıdığı yenilikçi fikirlerin tohumlarıdır. Bu yeni insanlar, değişimin kendilerinden başlaması gerektiğinin farkındadırlar. Nitekim Vera, insanın olumlu anlamda değişmesiyle beraber yaşadığı toplumun da zamanla değişeceğini gösteren güzel bir örnektir. Çünkü kendi hayatında gerçekleştirdiği bireysel içsel devrim sayesinde düşlenen yeni toplum düzeni ütopik bir hayal olmaktan çıar ve toplumsal bir boyut kazanır. Yazar bu duruma dikkat çekmek amacıyla romanın önsözünde, Rusya'da azınlık da olsa, eylem insanlarının varlığına şu sözlerle hitap eder:

"Ey iyi insanlar, güçlü, dürüst, yetenekli insanlar! Siz bir süredir görünmeye başladınız aramızda, ama artık sayınız az değil ve hızla çoğalıyorsunuz. (...) Siz daha çoğunluk değilsiniz ama okurlarım arasında da varsınız, bu yüzden de ben şimdilik yazmak zorundayım.” (Çernişevski, 2003: I/30).

Yazar yine aynı bölümün devamında açık bir dille romanını kendisinin aksine rejime bağlı olanlar için yazdığını belirtir. Yazar, romanı aracılığıyla düş gibi görünenlerin aslında gerçeğe dönüşebilmesinin eyleme geçip inanma gücünü aktifleştirmekle mümkün olduğunu gösterme amacındadır. Çağdaş edebiyat eleştirmenlerinden Anton Demçenko'ya göre (2009: 37) romandaki ütopik betimlemeler, iki açıdan önemlidir. Birincisi, yazar benimsemiş olduğu toplumsal ve ahlaki ideali somutlaştırma imkânı yaratır. İkincisi, okuyucuyu ikna etmek için yeni toplumsal ilişkilerin gerçekte de olabileceği inancını aşlamaktır.

Nekrasov ve Panayev geçmiş, Belinski’nin de büyük katkılarıyla, dergi demokratik yönelimin en etkin yayın organı haline gelmiştir. Bkz: Olcay, T. (2003). Rus Edebiyatında Doğalcı Okul. Istanbul: İstanbul Üniversitesi Yayınları. s.71.

Adres

İstanbul Medeniyet Üniversitesi, Eğitim Bilimleri Fakültesi, Türkçe ve Sosyal Bilimler Eğitimi Bölümü, Türkce Eğitimi ABD Cevizli Kampüsü, Kartal-İstanbul/TÜRKIYE e-posta: editor@rumelide.com
Address

Istanbul Medeniyet University, Faculty of Education Sciences,

Turkish and Social Scinces Education, Turkish Language Teaching

Education, Cevizli Campus, Kartal-İstanbul /TURKEY

e-mail: editor@rumelide.com 
XIX. yüzyılın ikinci yarısında Rus edebiyatı için yeni bir imge olarak beliren Turgenyev'in Bazarov'u, Çernişevski’nin “yeni insan” tipinin kökü niteliğindedir. Bu bağlamda ilk olarak Dimitri Sergeyeviç Lopuhov'u incelemek gerekmektedir. Çünkü Lopuhov soyadı, Bazarov'un bir köylü hakkında konuşurken sarf ettiği cümlelerinden filizlenir: "O beyaz bir evde yașayacak, benim üzerimde ise dulavratotu bitecek, sonra ne olacak?” (Turgenyev, 2010: 224) (“Нy, будет он жить в белой избе, а из меня лопух расти будет; - ну, а дальше?”) (Кантор, 2017: 178). Lopuhov, bir toprak sahibinin oğlu, Kirsanov'un üniversiteden arkadaşı ve Vera'nın eşidir. Tıp fakültesi öğrencisidir. Proseför olmayı ve prestijli bir işinin olmasını hayal eder. Çok çalışkan ve amaçları doğrultusunda kimseden yardım almadan azimle yol alan bir kişiliğe sahiptir. Hayattan ne istediğini bilir. Ders vererek hayatını idame ettirir. Bu süre zarfında Vera ile tanışır. Ancak Vera ile tanıştıktan sonra hayatı değişir. Vera'ya yardımcı olmak için eğitimine ara verir. Bu esasen Lopuhov'dan beklenmeyecek bir davranıştır. Lopuhov, kendi parlak kariyerine devam etmek yerine Vera'nın hayatına dokunarak daha büyük bir eyleme imza atmak ister. Öte yandan Lopuhov'un Vera'nın gelişimi uğruna kendi kişisel kariyerine ara vermesi, çevresindekilerin bireysel özgürlüğüne verdiği önemle ilişkilendirilebilir. Lopuhov, Vera'nın düşüncel anlamda aydınlanmasını sağlar. Bu sayede Vera, kabuğunu kırma cesareti gösterir. Ancak Lopuhov, Vera ile olan ilişkisini noktalamak durumunda kalır. Bu durumun sebebi, evlerine sıklıkla ziyarete gelen Kirsanov ve Vera arasında yaşanan yakınlaşmadır. Lopuhov'un ardından Vera'nın Kirsanov'a yakınlık duyması, evde yalnız kaldığı zaman diliminde aralarında geçen düşünsel paylaşımların kendisinde yarattığı etkiyle ilişkilendirilebilir. Bu noktada romanda bir diğer "yeni insan" tipinin temsilcisi olan Aleksandr Matveyeviç Kirsanov'a daha yakından bakmak ve Lopuhov ile ortak yanlarına değinmek gerekmektedir. Romanda Avrupai bir kahraman olarak karşımıza çıkan Kirsanov, Lopuhov gibi tipik bir demokrattır. Her ikisi de yalnızca eski dünya düzenini yıkmak değil, aynı zamanda yenisini inşa etmek emelindedir. Bazarov'un aksine, sanattan da keyif alırlar. Bilhassa Kirsanov, müziği ve operayı tutkuyla sever. Lopuhov ise oldukça iyi piyano çalar. Her ikisi de doğanın mucizevi güzelliğinin farkındadırlar. Onlara göre "insan" yeni formlar oluşturabilen yaratıcı ruha sahip bir varıktır. Kadınların özgür ve eşit haklara sahip olmaları gerektiğini düşünürler ve kadınlara dayanışma sağlama bilincindedirler. Kirsanov "Seven insan, sevdiği kadını bağımsızhğa yücelten insan!” (Çernişevski, 2003: II/166) düşüncesini savunur. Çünkü onlara göre “özgürlüğün olmadığ yerde, mutluluk yoktur.” İnsanlar arasındaki dostluğun kutsallığına inanırlar. Lopuhov ve Kirsanov gibi "yeni insanlar" serinkanlı ama sıcakkanlıdırlar:

\begin{abstract}
"Onların en belirgin bir şekilde ortaya çıkan yanları, tek tek, yani birey olarak özellikleri değil, tipleridir (...) Bu insanlar başkaları arasında, tıpkı Çinliler arasında yaşayan birkaç Avrupalı gibidir; Çinliler asla onları birbirinden ayıramazlar (...) Lopuhov'la Kirsanov'un tipinden olanlara, hep birbirlerinin aynısı insanlarmış gibi görünürler. Bunların hepsi de yüreklidir, korku nedir, ikirciklenme, kararsızlık nedir bilmezler, hiçbir engel karşısında gerilemezler, ellerinden iş gelir, bir işe sarıldılar mı, tamam artık, o iş̧ kesinlikle sonuçlandırılacaktır; bu onların özelliklerinin bir yanıdır; bir başka özellikleriyse son derece namuslu olmalarıdır (...)" (Çernişevski, 2003: I/241242).
\end{abstract}

Alıntıdan da anlaşıldığı üzere birbirine karakter olarak çok benzeyen Lopuhov ve Kirsanov'un hayat felsefelerinin aynı olduğundan Vera'yı etkilemeleri tabii bir durum olarak değerlendirilebilir. Yakın arkadaşı olan Kirsanov ile eşi Vera arasındaki yakınlaşmayı fark eden Lopuhov, onların mutluluklarına engel olmamak adına intihar etmiş süsü vererek gizlice yurtdışına gider. Böylelikle Vera, resmi olarak Kirsanovla evlenme imkânı bulur. Lopuhov ise Amerika'da zaman içinde zenginleşir. Bir Amerikalı görünümde eserin sonlarına doğru Petersburg'a geri döner. Burada kendisini yeni ve bambaşka bir hayatın içinde bulur. Varlıklı bir ailenin kızı olan Yekaterina ile evlenir. Bu bağlamda "yeni insanlar"ın kendi hayatlarını yeniden kurma özelliği gösterdikleri görülür. Eserin sonunda ise her iki çift, Petersburg'da birbirlerine yakın evlerde yaşarlar.

Adres

İstanbul Medeniyet Üniversitesi, Eğitim Bilimleri Fakültesi, Türkçe ve Sosyal Bilimler Eğitimi Bölümü, Türkçe Eğitimi ABD Cevizli Kampüsü, Kartal-İstanbul/TÜRKIYE e-posta: editor@rumelide.com
Address

İstanbul Medeniyet University, Faculty of Education Sciences,

Turkish and Social Scinces Education, Turkish Language Teaching

Education, Cevizli Campus, Kartal-İstanbul /TURKEY

e-mail: editor@rumelide.com 
Çernişevski’nin "yeni insanlar”ı yaşadıkları bireysel değişimlerin yanı sıra, toplumsal yapıya ilişkin değişikliklerin de icra edilmesi düşüncesindedir. Romanda yeni Rus toplum düzeni, daha çok Vera'nın rüyası aracılığıyla okuyucuya aksedilir. İnşa edilen yeni düzende bütün işler ortaklaşa yapılır ve yemekler hep birlikte yenilir. Herkes için her şeyin eşit olduğu bir düzen esastır. Bu durumun temeli Çernişevski'nin yararcılığa, rasyonalizme ve eşitlikçiliğe öncelik veren rasyonel egoizm 5 (akılcı bencillik) kuramına dayanır. Akılcı bencil, tüm insanların eşit olduğunu kabul ettiği için ortak çıarları gözetmeyi ve birbirlerine yardım etmelerini savunur. Andrey Walicki (2009: 304-305) ise Alman filozof Ludwig Feuerbach'nn "Birey varlık olmak, bencil bir varlık olmak anlamina gelir; dolayısıyla (ister istemez) bir Communist (komüncü, toplulukçu, komünist) olmak anlamina gelir" cümlesinin Çernişevski'nin sosyalist düzeni savunan "rasyonel egoist”leri anlattığı Nasıl Yapmalı romanının sloganı olabileceğini belirtir. Romanda eşit bir düzen anlayışının savunulması şu sözlerle ifade edilir:

"Kârı her ay aralarında bölüşüyorlardı. (...) Sonra bir adım daha ileri gittiler; her gün tükettikleri ekmek ve benzeri şeyleri de toptan almalarının daha uygun olacağını gördüler. Ama bu noktada toplu halde yaşamaları gerektiğini anladılar. (...) ...yiyeceklerini büyük işletmelerde olduğu gibi toptan alıyorlar, yemeklerini hep birlikte yiyorlardı." (Çernişevski, 2003: I/220).

Küçük bir atölyeyle çıkılan yolda kat edilenlere bütünsel olarak bakıldığında, kurulan yeni düzen sonrasındaki tablonun bir prototipi olduğu yargısında bulunulabilir. Bu bağlamda Vera Pavlovna'nın rüyasında anlatılan yeni düzen toplumunda herkes bir eylem insanıdır. Çoğunlukla herkes tarımla ilgilenir:

“Tarlalara öbek öbek insanlar dağılmış durumda; kadın, erkek, yaşlı, genç, çocuk, herkes hep birlikte. (...) Tarlalarda çalışanlar şarkı söylüyorlar. İyi ama ne yapıyor onlar tarlalarda? Ah, ekin biçiyorlarmış!" (Çernişevski, 2003: II/182-183).

Vera Pavlovna'nın dördüncü rüyasının sonunda “yeni insanlar”ın karakter özellikleri ve bunlara dair değerlendirmeler verilir. Romandaki “yeni insan”lar, hayatın içinden sıradan insanlardır:

"Yeni insanlar diye birileri vardır ve bunlar yalnızca kendileri bu niteliklere sahip olmakla kalmazlar, aynı üstün niteliklere sahip olmayanlarla dostluk, arkadaşlık da etmezler; ancak onlar bunu yaparken dostlarını, arkadaşlarını olağanüstü insanlar olarak değil, iyi yürekli, basit, sıradan insanlar olarak görürler" (Çernişevski, 2003: II/163).

Dönemin baskıcı yönetimi yüzünden Çernişevski, devrim yolunu işaret eden düşüncelerini kahramanları aracılığıyla aktarır. Bu bağlamda ilk olarak kitap okumanın önemine dikkat çeker. Eğitimli ve farkındalık düzeyi yüksek olan bireyler sayesinde, Rus toplumunun daha ileriye taşınabileceğinden ve bu hususa dair gerekliliklerden bahseder. Yazarın düşünsel ve ruhsal gelişimde rahip olan babası Gavriil İvanoviç̧in rolü büyüktür. Kendini geliştirme yolunda okumanın gücüne inanan baba, oğlu Çernişevski'nin eğitimiyle doğrudan ilgilenir (Gürsoy, 2014: 44). Bu durumun kendisine sağladığı faydayı bizzat deneyimleyen Çernişevski, ideal bir toplumun oluşturulmasında eğitimin en etkin faktör olduğunun farkındadır. Bu yüzden eserde okumanın ve kendini geliştirmenin ne denli önemli olduğunu vurgular:

"Vera Pavlovna kuruluşlarının daha ilk günlerinden başlayarak atölyeye kitap taşımaya başladı. O günkü işlerle ilgili yönergelerini verdikten sonra yüksek sesle kitap okumaya başlıyordu. (...) ara vermeden yarım saat, bir saat kadar okuyordu. (...) Daha ilk günden başlayarak kızların bu okuma

\footnotetext{
5 "Rasyonel Egoizm" bizim genellikle bencillik olarak anladığımız şeyden büyük ölçüde ayrılmaktadır. Çernişevski, "egoizm" terimini, etik kuramında, aşkın değerler adına, baskı altındaki insanların durumları iyileştirmek yolundaki tüm girişimlerini "bencillik" olarak suçlayanlara meydan okumak amacıyla kullandı; bu, insanlardan, yüksek oldukları ileri sürülen amaçlar adına kendilerini feda etmelerini isteyen ideolojilere karşı duyduğu güvensizliğin bir simgesiydi. Bkz: Walicki, A. (2009). a.g.e., s.305.
}

Adres

İstanbul Medeniyet Üniversitesi, Eğitim Bilimleri Fakültesi, Türkçe ve Sosyal Bilimler Eğitimi Bölümü, Türkce Eğitimi ABD Cevizli Kampüsü, Kartal-İstanbul/TÜRKIYE e-posta: editor@rumelide.com
Address

Istanbul Medeniyet University, Faculty of Education Sciences,

Turkish and Social Scinces Education, Turkish Language Teaching

Education, Cevizli Campus, Kartal-İstanbul /TURKEY

e-mail: editor@rumelide.com 
saatlerine büyük bir ilgi duyduklarını söylemek gereksiz olacak. (...) Bu kızların kitap okudukları yarım saat bir saatlik süre onlar için yine iş zamanı yazılacaktı" (Çernişevski, 2003: I/222).

Bilhassa kitap okumanın kişinin karakteri üzerinde yarattı̆̆ı etkilere değinerek eğitimin sağladı̆̆ı farka dikkat çeker. Bahsi geçen durum romanın ana kahramanlarından Vera Pavlovna üzerinde belirgin bir şekilde gözlenir. Vera, yalnızca kendi seçimleriyle okuduğu romanlarla kişisel gelişimini yukarıya taşıyamayacağının farkındalığı içindedir. Kardeşinin öğretmeni olan tıp öğrencisi Lopuhov’un okumuş olduğu bilimsel kitaplar, Vera'nın vizyonunun gelişmesini sağlar: "Birtakım iyi insanlar, akıllı insanlar yazdıkları kitaplarda dünyada herkesin güzel yaşaması için nelerin yapılması gerektiğini açıladılar. Onlarm düşüncelerine göre örneğin bir atölye kurulacaksa bu yeni düzene göre kurulmahdır" (Çernişevski, 2003: I/216). Hatta daha sonrasında Vera, Kirsanovla olan beraberliğinin kendisinde yarattığı etkileri şu sözlerle net bir dille aktarır:

\begin{abstract}
"Benim şimdiki düşüncelerim beş yıl önceki düşüncelerimden çok daha geniş boyutlu. Ve ben durmadan geliştiğimi hissediyorum; sen olmasaydın bende bu gelişmeler olmazdı. (...) Sen bana ilk gençliğimin canlılığını, diriliğini verdin, beni durup kaldı̆̆ım yerden çıkaracak, ilerilere götürecek gücü verdin; sen olmasaydın benim o durup kaldığım yer, hayatta ulaştığım son yer olacaktı." (Çernişevski, 2003: II/165).
\end{abstract}

Vera, okuduklarını teoride bırakmayarak uygulamaya da koyduğunu göstermek amacıyla bir dikiş atölyesi açar. Açtığı bu atölyede çalışan kadınlara okuma alışkanlığını aşılar. Diğer yandan da eşi Lopuhov'dan destek alarak kadınların ders almalarını sağlar. Böylelikle çevresindekiler arasında yarattığı sinerji sayesinde sıradan insanların kişisel dönüşümlerine tanıklık edilir. Vera'nın bu bağlamda en önemli kişisel özelliği yalnızca kendi kişisel gelişimi için değil, aynı zamanda çevresindekilere de kendi düşünce felsefesini sirayet ettirmeyi başarmasıdır.

Çernişevski içinde bulunduğu toplumda kadının iş hayatında yerinin olmamasını eleştirir. $\mathrm{Bu}$ çerçevede Vera'nın doktor olmasıyla yarattı̆̆ı örneklem üzerinden eleştirisini somutlaştırdı̆̆ görülür:

"Vera Pavlovna da işte böyle tıpla uğraşmaya başladı, ülkemizin bu alana el atan ilk kadınlarından biri oldu. (...) Şöyle düşünüyordu: "Birkaç yıl sonra yalnızca kendi ayaklarım üzerinde durabileceğim.” Gerçekten çok yüce bir düşünce bu. Tam bağımsızlık olmadı mı, tam mutluluk da yoktur" (Çernişevski, 2003: I/155-156).

Yazara göre olması gereken ideal toplumda kadın ile erkek her alanda eşit haklara sahip olmalıdır. Bu düşünceyle Çernişevski, bilhassa Vera Pavlovna üzerinden, kadının toplumdaki yerine ve üstlendiği misyona dikkat çeker. Yazara göre kadın, her anlamda kendine yeten, bağımsızlığına önem veren ve farkındalığı yüksek bir birey olma özelliği taşımalıdır. Nitekim romanda Vera, kendi özgürlüğü ve geleceği için yaptıklarıyla kadının bireysel olarak değişmesiyle toplumun kalkınmasının gerçekleşebileceği inancını göstermektedir. Bu bağlamda hiç şüphesiz yazarın kadın kahramanın ismini Rusçada "inanç" anlamına gelen "Vera" olarak tercih etmesinin tesadüfi olmadığı anlaşılmaktadır.

Vera, ailesinin önerdiği zengin talibi yerine hayat felsefesinin uyuştuğu Lopuhov ile gizlice evlenmeyi tercih eder. Bu evliliği boyunca kendine çok sayıda kazanım sağlar. İkinci evliliğini ise doktor Kirsanov ile yapar. Her iki evliliğinde de Vera aynı düşünce yapısına sahiptir. Çünkü hem Lopuhov hem de Kirsanovla olan ilişkisinde odak noktası, yalnızca kendi kişisel gelişimidir. Onlardan alabileceği faydalı yanları kendine katmaya çalışmasıdır. Vera'nın daha sonrasında eşinin de desteğiyle doktor olması, bu duruma yönelik bir örnektir. Böylelikle yazarın kadın ve erkek eşitliğine de dikkat çektiği anlaşılmaktadır: 


\begin{abstract}
"Kamusal hayatın bütün kapıları kadınların yüzüne resmen kapatılmış durumda. (...) Hayatın bütün alanları içinde bize bırakılmıș tek bir alan var, aile... Bizim ailenin bir üyesi olmamızdan başka bir şey olmamıza izin verilmiyor (...) Yalnızca çocuk bakıcılığı... (...) Kadınlar bugün ciddi işlere girebilecek durumda değiller, çünkü bu tür işler için gerekli bilgi ve beceriyle donatılmış değiller (...) Kocam doktor. İşinden arta kalan bütün zamanını bana veriyor. Böyle bir kocam olduktan sonra doktor olup olamayacağımı kolayca deneyebilirim” (Çernişevski, 2003: II/153-154).”
\end{abstract}

Romanda toplumun mihenk taşı olan aile düzeninin nasıl olması gerektiğine dair bilgiler de paylaşılır. Yazarın aile temasına değinmesi, yeni ve ideal toplum düzenindeki ilişkileri göstermesi bakımından gerekli ve önemlidir. Eş seçiminin önemi, Vera örneği üzerinden gösterilmektedir. İnsanın birliktelik kurduğu kişi, kendi aynası niteliğindedir. Aralarındaki düşünsel paylaşımlar, dolaylı şekillerde de olsa toplumu etkilemektedir. Bu yüzden mutlu bir aile hayatının yanı sıra, boşanmanın da son derece tabii bir durum olduğu düşüncesi ileri sürülmektedir. XIX. yüzyll toplum düzeninde böyle bir fikrin sunulması, hiç şüphesiz yazarın ne denli ileri görüşlü olduğunun göstergesidir. "Yeni insanlar"ın ahlaki değer yargıları, aşka ve evliliğe dair düşüncelerinden okunur. En önemlisi ise kendi öz benlikleridir. Aşk ilişkisinde dikkat ettikleri husus, ruhların karşlıklı beslenmesine dayalıdır. Bilhassa Vera'nın bakış açısı bu yöndedir:

"Saşa, aşkın öyle büyük bir güç veriyor ki... bu güçle bağımsız oluyorum, hatta sana bir bağlı olmaktan çıkıyorum. Ya benim aşkım sana ne veriyor?" "Senin aşkın bana?.. Aynı gücü veriyor... Bu güç, sinirlerim için sürekli, güçlü ve sağlıklı bir uyaran oluyor, sinir sistemimi geliştirip güçlendiriyor (...) böylece aşkın bende yeni yeni zihni ve ahlaki güçler geliştiriyor" (Çernişevski, 2003: II/164).

Çernişevski yarattığı "yeni insanlar" aracılığıyla bütünsel bir özgürlük tablosu çizer. Vera her iki evliliğinde de kendine ait bir odasının olmasına önem verir. Eşlerinden ayrı odada kalması, kendi kişisel özgürlüğüne verdiği değerle ilişkilendirilebilir. Vera'nın kendini geliştirme imkânı bulduğu alan, kendi odasıdır:

"Bence dinlenmek yalnız kalmaktır, başka tür bir dinlenme benim anlayabileceğim bir şey değildir. Başkalarıyla birlikte olmak, benim için çalışmak, bir şeylerle meşgul olmak gibidir. Benim kendimi tümüyle serbest hissedebilmem yapayalnız kalmama bağlıdır. Bu nerden kaynaklanıyor? (...) ... ben açık ve içten bir insanım, içime kapanıp dünyaya kara kara bakmayı sevmem, her zaman neşeli olmak isterim. İnsanları izlemekten, onlarla birlikte olmaktan hoşlanırım; ama bütün bunlar benim için daha sonra dinlenmeyi, yalnız kalmayı gerektiren bir tür çalışma ya da zevk almadır. Anlayabildiğim kadarıyla bağımsızlığa ve özgürlüğe aşırı tutkunluğumdan kaynaklanmış bir duygu bu bende." (Çernişevski, 2003: I/113)

Yazarın böyle bir fikri güçlü kılmasından kişinin kendi gelişimine önem vermesi ve hayatı boyunca en büyük değer yargısının bu olmasına özen göstermesi gerektiği sonucuna varılabilir. Mevcut toplum düzeninde aşă̆ılanan kadının yerini Vera gibi erdemli ve vizyon sahibi kadınlar almalıdır. Çernişevski yeni bireylerin yetiştirilmesinde kilit rol oynayan kadınların eşit haklara sahip olmalarına ve özgür olmalarına verdiği önemi Vera üzerinden vurgular.

Çernişevski bir diğer "yeni insan” tipi Rahmetov, romanda XIX. yüzyılın 6o’lı yllarının "özel insanı" olarak timsalleştirilir:

"Sayıları neredeyse bir elin parmağını geçmeyen devrimcilerden biri” olan Rahmetov, atılgan, kararlı, özverili, korku nedir bilmeyen, zorluklar karşısında yılgınlı̆̆a kapılmayan kusursuz bir insandır. Rahmetov'a verilen göreve bitmiş gözüyle bakılır; noktası noktasına yerine getirir üzerine aldığı işi. Toplumsala boyun eğmeyen kişisel hiçbir şeyi yoktur. Kendisini "işi”ne öylesine verir ki, çok geçmeden onunla bir beden olur, "iş"i artık onun kişisel yaşamıdır" (Çernişevski, 2003: I/1314).

Adres

İstanbul Medeniyet Üniversitesi, Eğitim Bilimleri Fakültesi, Türkce ve Sosyal Bilimler Eğitimi Bölümü, Türkçe Eğitimi ABD Cevizli Kampüsü, Kartal-İstanbul/TÜRKIYE e-posta: editor@rumelide.com
Address

Istanbul Medeniyet University, Faculty of Education Sciences,

Turkish and Social Scinces Education, Turkish Language Teaching

Education, Cevizli Campus, Kartal-İstanbul /TURKEY

e-mail: editor@rumelide.com 
Devrimci ruhun en belirgin şekilde Rahmetov'da hissedilmesinden dolayı bir nevi Çernişevski'nin bizzat kendisinin bir yansıması olduğu da söylenebilir. Nitekim Polonyalı tarihçi Andrzej Walicki (2009: 294-295) Rusya'da devrimci gidişin hızlanmasıyla, radikal kampın düşünsel önderi olarak Çernişevski'nin oynadığı rolün önemini ifade eder. Hatta evinin odalarının devrimci eylemcilerin buluşma yeri haline gelmesi ve öğrencilerin siyasi nitelikli gösterilerini tartışmak için toplanmaları bu durumun somut örneklerinden biri olarak gösterilebilir. Tıpkı Vera'da olduğu gibi, Rahmetov da öğrenme arzusunu kitaplar aracıllğıyla baskılar. Diğerlerinin aksine Rahmetov, soylu bir aileden gelir. Rahmetov ruhunda duyumsadığı boşluğu sahip olduğu maddi olanakların verdikleriyle değil, üniversitede tanıştığı tıp öğrencisi Kirsanov sayesinde doldurur. Kirsanov’un önerdiği kitaplarla vizyonunu geliştirir. Bir yandan seyahat eder, diğer yandan topluma faydalı eylemlerde bulunmaya çalışır. Zaman içinde toplumda devrim gerçekleştirmek, Rahmetov'un yaşam amacına dönüşür. Bu uğurda hayatının aşkından vazgeçecek kadar büyük fedakarlıklar yapar. Rahmetov, tüm hayatını devrime adamış olan gerçek bir devrimcinin timsalidir. Yeni ahlaki değerleri ve yeni bir hayat felsefesini benimsemiş olan "yeni insanlar" devrimin kaçınılmaz olduğunun farkındadırlar. Verhovskiy'e göre (1959: 20) onların sayesinde toplumun her tabakası gelecekte mutluluğu tadabilir. Vera Pavlovna, Lopuhov, Kirsanov ve Rahmetov için emek vermek bir gerekliliktir. Çünkü emek demek bir ilerlemedir, gelişimdir, mutluluktur. "Yeni insan"lar başka insanların mutluluğu için mücadele verilmezse mutlu olunamayacağı düşüncesindedirler. Hayatlarını halka adamışlardır. Kirsanov gönüllü olarak yoksulları tedavi eder, Vera Pavlovna'nın atölyesinde çalışan kızlara seve seve ders verir. Çevrelerindeki insanların hayatlarını kolaylaştırırken kendileri bundan büyük bir mutluluk duyarlar: "Başkasınin yücelmesine yardım etmede ve kendini yüceltmededir aşk" (Çernişevski, 2003: II/165). Romanda Fransız halk şarkısı "Caira”ya yer verilmiş olması, 1789'da gerçekleşen Fransız Devrimine ithafendir. Çünkü Çernişevski'ye göre emek vererek aydınlanmanın ve devrimin gerçekleşmesi halinde insanlık için mutlu bir gelecek mümkündür:

"Güneş doğuyor, doğa sevinç içinde; yürekler ışık ve sıcaklık, şarkı ve sevgi, sevinç ve sevdayla doluyor; sevgi, sevinç, mutluluk şarkıları kopuyor bütün yüreklerden” (Çernişevski, 2003: II/169).

\section{Sonuç}

Çernişevski’nin düşlediği devrimi gerçekleştirecek “yeni insanlar” ın özelliklerini aktarırken devrim için izlenmesi gereken yolu ve yaşam biçimlerinin nasıl olması gerektiğini göstermeye çalışan bir yazar olduğu anlaşılmaktadır. Çalışmamızda "yeni insanlar"ın timsali olan Lopuhov, Kirsanov, Vera ve Rahmetov; Rus edebiyatında sıklıkla görülen "gereksiz insan”lardan farklı olarak güçlü iradeye sahip, rasyonalist, eylem insanı, mutluluk odaklı, herkesi düşünen, pragmatizmi benimsemiş topluma rol model olma nitelikleriyle karşımıza çıkmıştır. Söz konusu "yeni insan" tiplerinin gelecek neslin bilinçlenmesini sağlayacak ve yeni dönem Rusya’sının ruhunu sil baştan yeşertecek özellikler taşıdığı gözlenmiştir. Bu özellikler genel hatlarıyla şu şekilde bütünsel olarak sunulabilir:

- Kişinin bireysel özgürlüğünü her şeyden üstün tutarlar.

- Toplum yararına ve iyiliğine kendilerini adarlar.

- Rasyonel egoizmi (akılcı bencillik) benimseme özelliği gösterirler.

- Kendi kişisel gelişimlerine önem verirler.

- Kendi hayatlarını yeniden kurma cesaretine sahiptirler.

- Kadınların eşit haklara sahip ve özgür olmalarına değer verirler.

- Yalnızca bireysel değişimlerin değil, aynı zamanda toplumsal yapıya ilişkin değişikliklerin de icra edilmesi düşüncesindedirler.

\footnotetext{
Adres $\mid$ Address

İstanbul Medeniyet Üniversitesi, Eğitim Bilimleri Fakültesi, Türkçe İstanbul Medeniyet University, Faculty of Education Sciences, ve Sosyal Bilimler Eğitimi Bölümü, Türkce Eğitimi ABD Cevizli Turkish and Social Scinces Education, Turkish Language Teaching Kampüsü, Kartal-İstanbul/TÜRKIYE $\quad$ Education, Cevizli Campus, Kartal-İstanbul /TURKEY e-posta: editor@rumelide.com 1 e-mail: editor@rumelide.com
} 
- İnsanlık için her şeyin eşit olduğu bir düzen anlayışından yanadırlar.

- Düşledikleri yeni düzen toplumunda her birey bir eylem insanıdır.

- Eğitimli ve farkındalık düzeyi yüksek olan bireylerdir.

- Rus toplumunun daha ileriye taşnabilmesi için ilgili tüm gereklilikleri yerine getirmeye hazırdirlar.

- Bilhassa kitap okumanın kişinin karakteri üzerinde yarattığı etkiye ve eğitimin sağladığı farka dikkat çekerler.

- Aşk ilişkisinde dikkat ettikleri husus, ruhların karşılıklı beslenmesine dayalı olmasıdır.

- Devrimin kaçınılmaz olduğu inancını taşırlar.

Bu çerçevede Çernişevski'nin Nasıl Yapmalı? adlı romanının kendi döneminin "yeni insan" tiplerini tanıtması bakımından Rus edebiyatında önemli bir yere sahip olduğu yargısında bulunulabilir. Araştırmacı yazar Mehmet Tekin’in (2018: 112) "Roman Sanatı" adlı çalışmasında tarihsel önemi veya toplumsal konumu hemcinslerinden farklı olan bir roman kahramanı olarak tanımladığı "tip" kavramından yola çıkarak ise Çernişevski'nin "yeni insanlar" tipinin ortaya konulmasının bir gereklilik sonucu olduğunu söylemek mümkündür. Çünkü toplumsal ve siyasi düşünceler ışığında şekillenen Çernişevski’nin "yeni insanlar" 1 ile dönemin toplumsal sorunlarını irdelemeyi amaçladığı anlaşılmaktadır. Romanın başlı̆̆ındaki Nasıl yapmalı? sorusunun yanıtı, insanların içinde bulundukları zor koşullardan sıyrılabilmelerinin kendi ellerinde olduğu ve yaşanan acıların içinde mutluluğu da bulabilecekleri düşüncesini uyandırmaktadır. Bu bağlamda söz konusu romandaki "yeni insan” tiplerinin gelecek neslin yetişmesinde ve yetkinleşmesinde sağladığı değer açık bir şekilde gözlenmektedir.

\section{Kaynakça}

Çernişevskiy, N. (2003). Nasıl Yapmalı?. Cilt 1-2. çev. Mazlum Beyhan. İstanbul: Evrensel Basım Yayın.

Franckh, P. (2020). Rezonans Kanunu. İstanbul: Koridor Yayıncılık.

Gürsoy, Y. (2014). Nikolay Çernişevski ve Devrimcinin El Kitabı “Nasıl Yapmalı?”, Rusya'da Eylemin Sanatla Buluşması kitabı içinde (44-54.ss.), İstanbul: Çeviribilim Yayınları.

Olcay, T. (2003). Rus Edebiyatında Doğalcı Okul. İstanbul: İstanbul Üniversitesi Yayınları.

Süer, Ö.A. (1994). XIX. Yüzyıl Rus Edebiyatı Üzerine Yazılar. İstanbul: Evrensel Basım Yayın.

Tekin, M. (2018). Roman Sanatı 1, Romanın Unsurları. İstanbul: Ötüken Yayınları.

Turgenyev, İ. (2010). Babalar ve Oğullar. (Çev. Ayşe Hacıhasanoğlu). Can Yayınları.

Walicki, A. (2009). Rus Düşünce Tarihi Aydınlanma'dan Marksizme. (Çev. Alaeddin Şenel.) İletişim Yayınları.

Balahonovaya, A.A. (2018). Roman N.G. Çernışevskogo "Şto Delat?": Temı, Struktura, Sistema obrazov. Belgorog: Belgorodskiy Gosudarstvennıy Natsionalnıy Issledovatelskiy Universitet.

Vayl, P.L. (1991). Roman veka: “Şto Delat?” N.G. Çernışevskogo (Tekst). Moskva: Rodnaya reç. 125132.

Verhovskiy, G. (1959). O romane N.G. N.G. Çernışevskogo (Tekst). Moskva: Nauka. No: 3. 18-33.

Demçenko, A.A. (2009). Nikolay Çernışevskiy: K180-letiyu so dnya rojdeniya (Tekst). İzvestiya Saratovskogo universiteta. Saratov: İzvestiya. T. 9. Vipusk.1. 36-44.

Kantor, V.K. (2017). "Podpolnıy çelovek" protiv "novih lyudey", ili O torjestve zla v miroustroysve". Vestnik kulturologii// Çelovek i kultura. No: 1(80). 155-182.

\footnotetext{
Adres $\mid$ Address

İstanbul Medeniyet Üniversitesi, Eğitim Bilimleri Fakültesi, Türkçe ve Sosyal Bilimler Eğitimi Bölümü, Türkce Eğitimi ABD Cevizli Turkish and Social Scinces Education, Turkish Language Teaching Kampüsü, Kartal-İstanbul/TÜRKIYE $\quad$ Education, Cevizli Campus, Kartal-İstanbul /TURKEY e-posta: editor@rumelide.com 1 e-mail: editor@rumelide.com
} 
Çernışevskiy, N.G. (1937). İz avtobiografii (Tekst). Pod red. V.A. Suşitskogo. Saratov: Saroblgiz.

Pinayev, M.T. (1980). N. G. Çernışevskiy-romanist i “noviye lyudi” v literature 60-70-h godov. (Tekst). Russkaya literatura. Moskva: Literaturniye izvestiya. No: 4. 34-49. http://az.budclub.ru/c/chernyshewskij_n_g/text_oo48.shtml 